\title{
Pengaruh Model Pembelajaran Discovery Learning Terhadap Keterampilan Menulis Teks Eksplanasi Siswa Kelas VII MTSN Durian Tarung Padang
}

\section{Hidayati Azkiyaa ${ }^{a, 1}$, Romi Isnandab ${ }^{b, 2^{*}}$}

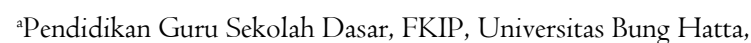

${ }^{\mathrm{b} P e n d i d i k a n}$ Bahasa Indonesia, FKIP, Universitas Bung Hatta,

'hidayatiazkiya@bunghatta.ac.id, ${ }^{2}$ romiisnanda@bunghatta.ac.id*

\begin{tabular}{ll}
\hline Informasi artikel & \\
\hline Sejarah artikel: & \\
Diterima & $: 03-10-2018$ \\
Revisi & $:$ I0-08-2018 \\
Dipublikasikan & : Januari 2019 \\
\hline
\end{tabular}

Kata kunci:

Teks Eksplanasi

Discovery learning

\section{Key word:}

Explanatory text

Discovery learning

\begin{abstract}
ABSTRAK
Penelitian ini bertujuan untuk menjelaskan perbedaan hasil belajar menulis teks eksplanasi yaitu: (I) antara siswa yang diajarkan menggunakan model pembelajaran discovery learning dengan siswa yang diajarkan menggunakan model pembelajaran konvensional, (2) interaksi antara model pembelajaran terhadap keterampilan menulis teks eksplanasi. Jenis penelitian ini quasi eksperiment dan desain yang digunakan adalah factorial $2 \times 2$. Pengambilan sampel dilakukan dengan cara purposive sampling. Analisis dan pembahasan data dilakukan secara deskriptif-analisis. Hasil analisis data yang dilakukan dapat disimpulkan. Pertama, menulis teks eksplanasi yang diajar dengan menggunakan model pembelajaran discovery learning lebih baik daripada siswa yang diajar dengan model pembelajaran konvensional. Kedua, tidak terdapat interaksi antara model pembelajaran dalam mempengaruhi kemampuan menulis teks eksplanasi siswa. Maka, dapat disimpulkan bahwa model pembelajaran discovery learning dapat mempengaruhi keterampilan menulis teks eksplanasi siswa MTsN Durian Tarung Padang.

ABSTRACT

This study aims to explain the differences in the results of learning to write explanatory text, namely: (I) between students taught using learning discovery learning model with students taught using conventional learning model, (2) interaction between learning model of explanatory writing skill. This type of research is quasi experiment and the design used is $2 \times 2$ factorial. Sampling is done by purposive sampling. Analysis and discussion of data is done descriptively. The result of data analysis can be concluded. First, writing explanatory texts that are taught using discovery learning learning model is better than students taught by conventional learning model. Second, there is no interaction between the learning model in influencing the ability to write explanatory text of students. Thus, it can be concluded that the learning model discovery learning can influence the skills of writing text eksplanasi MTsN students Durian Tarung Padang.
\end{abstract}

Copyright (C) 2018 Universitas Ahmad Dahlan. All Right Reserve

\section{Pendahuluan}

Pembelajaran bahasa Indonesia dalam Kurikulum 2013 berorientasi pada pembelajaran teks. Pembelajaran bahasa Indonesia bukan sekadar pengetahuan bahasa, melainkan sebagai teks yang berfungsi sebagai sumber aktualisasi diri penggunanya pada konteks sosial budaya akademis. Priyatni (20I4) menyatakan bahwa teks merupakan bahasa yang terdapat dalam suatu konteks situasi dan konteks kultural. Konteks situasi merupakan lingkungan langsung yang berada dalam teks, sementara kultural merupakan sistem nilai norma 
Hidayati Azkiya, dkk | Pengaruh Model Pembelajaran Discovery Learning

yang mempresentasikan suatu kepercayaan dalam suatu kebudayaan.

Salah satu pembelajaran menulis di tingkat SMP/MTs adalah menulis teks eksplanasi. Materi pelajaran menulis teks eksplanasi tercantum pada Kompetensi Inti (KI) dan Kompetensi Dasar (KD) tingkat SMP/MTs untuk kelas VII. Kompetensi Inti (KI) ke-4, yaitu siswa dituntut untuk mencoba, mengolah, dan menyaji dalam ranah konkret (menggunakan, mengurai, merangkai, memodifikasi, dan membuat) dan ranah abstrak (menulis, membaca, menghitung, menggambar, dan mengarang) sesuai dengan yang dipelajari di sekolah dan sumber lain yang sama dalam sudut pandang/teori. KD ke-4.2 menuntut siswa untuk menyusun teks hasil observasi, tanggapan deskriptif, eksplanasi, dan cerita pendek sesuai dengan karakteristik teks yang akan dibuat baik secara lisan maupun tulisan.

Teks eksplanasi merupakan teks yang berisi penjelasan tentang proses terjadinya suatu fenomena atau peristiwa, baik fenomena alam maupun sosial serta budaya secara ilmiah. Teks eksplanasi memiliki tujuan sosial untuk memaknai proses muncul atau terjadinya suatu peristiwa atau fenomena terkait dengan alam, sosial dan budaya. Oleh karena itu, teks eksplanasi dikategorikan ke dalam genre teks tanggapan (genre faktual) dengan tujuan untuk menjelaskan atau menganalisis fakta-fakta dalam proses terjadinya suatu peristiwa atau fenomena tersebut.

Selanjutnya, agar mampu menulis teks eksplanasi yang sesuai dengan tujuan pembelajaran, kompetensi yang harus dikuasai siswa adalah sebagai berikut. Pertama, siswa mampu mengusai aspek isi teks eksplanasi yang dilihat dari kesesuaian penjelasan dengan topik tulisan, logis, sistematis, dan komunikatif. Kedua, siswa mampu menguasai struktur teks eksplanasi yang terdiri atas, pernyataan umum,deretan penjelas, dan interpretasi/penutup. Ketiga, siswa mampu menguasai aspek kebahasaan dari teks eksplanasi yang meliputi ejaan (penggunaan huruf, penulisan kata, dan penggunaan tanda baca), diksi, dan kalimat efektif yang menjadi penanda keberadaan teks eksplanasi, sampai kepada upaya mencipta atau menyusun sendiri teks eksplanasi dalam bentuk lisan maupun tulis.

Berdasarkan observasi awal dan wawancara dengan guru mata pelajaran bahasa Indonesia kelas VII Ibu Liga Febrina, S. Pd. pada tanggal I3 Februari 2017 di MTsN Durian Tarung Padang, diperoleh informasi bahwa terdapat beberapa permasalahan yang dihadapi dalam penulisan teks eksplanasi di antaranya: (I) pemahaman siswa terhadap teks eksplanasi masih rendah, (2) keterbatasan pengetahuan, ide, dan gagasan dalam menyusun teks eksplanasi, (3) siswa kurang memahami struktur dan kaidah dari teks eksplanasi, (4) dalam menulis, siswa kurang memperhatikan tanda baca, diksi, dan kalimat efektif, (5) kurangnya motivasi siswa dalam pembelajaran bahasa Indonesia. Hal ini mengakibatkan rendahnya keterampilan siswa dalam menulis teks eksplanasi.

Model pembelajaran merupakan pola umum perilaku pembelajaran untuk membantu peserta didik memperoleh informasi, ide, kemampuan, nilai, cara berpikir, dan sarana mengekspresikan diri (Azkiya, 2017). Seperti model discovery learning berorientasi pada pembentukan pola pikir dan tindakan siswa agar lebih analitis, sistematis, logis, dan ilmiah. Melalui model discovery learning siswa dapat menemukan sendiri informasi serta konsep tentang materi pembelajaran. Siswa diajak untuk berpikir, berhipotesis, serta menguji hipotesisnya secara bersama-sama sampai menemukan kebenaran hipotesis yang dirumuskan dalam bentuk simpulan atau generalisasi. Hal ini sesuai dengan hasil penelitian Gusrayani (2016) bahwa model discovery mendorong perkembangan aktual dan perkembangan potensial siswa. Rangkaian kegiatan ini sangat cocok digunakan dalam pembelajaran menulis teks eksplanasi sebab teks eksplanasi merupakan teks yang berisi penjelasan tentang proses terjadinya suatu fenomena atau peristiwa, baik fenomena alam maupun sosial serta budaya secara ilmiah (Mubarak, 2014).

Berdasarkan uraian tersebut, penelitian ini mempunyai dua tujuan sebagai berikut. Pertama, menjelaskan perbedaan hasil belajar keterampilan menulis teks eksplanasi siswa yang diajar dengan menggunakan model pembelajaran discovery learning dengan siswa yang diajar dengan menggunakan model pembelajaran konvensional siswa kelas VII MTsN Durian Tarung Padang. Kedua,menjelaskan interaksi antara model pembelajaran dengan kemampuan menulis teks ekspanasi siswa skelas VII MTsN Durian Tarung Padang.

\section{Metode}

Jenis penelitian ini adalah penelitian kuantitatif (Arikunto, 2008). Prosedur dalam pengolahan data penelitian yang dilakukan dalam penelitian ini dituntut menggunakan angka-angka. Angka dalam penelitian ini adalah skor angket motivasi belajar serta skor dan nilai dari hasil tes menulis teks eksplanasi siswa kelas VII MTsN Durian Tarung Padang. Metode penelitian yang diterapkan adalah metode eksperimen. Penelitian ini dilakukan dengan menggunakan metode eksperimen semu (quasi exsperiment), yaitu penelitian yang bertujuan untuk 
Hidayati Azkiya, dkk | Pengaruh Model Pembelajaran Discovery Learning

memperoleh informasi dari eksperimen berdasarkan perlakuan (treatment) terhadap suatu unit percobaan dalam batas-batas desain yang ditetapkan pada kelas eksperimen sehingga diperoleh data yang menggambarkan apa yang diharapkan. Desain yang digunakan adalah faktorial $2 \times 2$ (Siregar, 2010). Pelaksanaan penelitian ini meliputi penyajian pembelajaran dengan menggunakan model pembelajaran discovery learning dan penyajian model pembelajaran konvensional. Populasi adalah siswa kelas VII MTsN Durian Tarung Padang yang terdaftar tahun pelajaran 2016-2017. Siswa kelas VII tersebut tersebar ke dalam enam kelas dengan jumlah 180 orang. Sehubungan dengan jumlah populasi besar dan lebih dari I00, maka perlu dilakukan penarikan sampel. Oleh sebab itu, pemilihan ini hanya menggunakan dua kelas yang akan ditetapkan sebagai sampel penelitian. Alat pengumpulan data yang digunakan dalam penelitian ini adalah tes keterampilan (tes unjuk kerja). Pengumpulan data dengan menggunakan tes unjuk kerja dalam menulis teks eksplanasi. Tes keterampilan dilakukan untuk mengukur tingkat keterampilan menulis teks eksplanasi.

\section{Hasil dan Pembahasan}

Pada bagian ini diuraikan data tentang pegaruh model pembelajaran discovery learning terhadap keterampilan menulis teks eksplanasi siswa kelas VII MTsN Durian Tarung Padang. Data penelitian secara keseluruhan pada kelas eksperimen dan kelas kontrol. Penjelasan tersebut meliputi: (a) hasil keterampilan menulis teks eksplanasi secara keseluruhan pada kelas eksperimen; (b) hasil keterampilan menulis teks eksplanasi secara keseluruhan pada kelas control. Pendeskripsian tersebut dijabarkan pada penjelasan berikut.

Tabel I. Data Hasil Tes Menulis Teks Eksplanasi Kelas Eksperimen

\begin{tabular}{cccccc}
\hline & $\begin{array}{c}\text { Nilai } \\
\text { Tertinggi }\end{array}$ & $\begin{array}{c}\text { Nilai } \\
\text { Teren } \\
\text { dah }\end{array}$ & X & N & S \\
\hline Eksperimen & 95,00 & 57,50 & 7 & 30 & I \\
& & & 8 & & 0, \\
& & &, & & 3 \\
& & & 7 & & 2 \\
& & & 5 & & \\
\hline
\end{tabular}

Berdasarkan tabel tersebut hasil tes keterampilan menulis teks eksplanasi yang dilaksanakan di kelas eksperimen dapat diuraikan bahwa nilai rata-rata untuk kelas eksperimen 78,75 dengan jumlah siswa 30 orang. Nilai maksimal yang diperoleh siswa di kelas eksperimen adalah 95 dengan frekuensi 2 orang sedangkan nilai minimum untuk kelas eksperimen adalah 57,50 dengan frekuensi satu orang. Sementara itu, simpangan baku pada kelas ekperimen adalah I0,32.

Tabel 2. Data Hasil Tes Keterampilan Menulis Teks Eksplanasi Kelas Kontrol

\begin{tabular}{cccccc}
\hline Kelas & $\begin{array}{c}\text { Nilai } \\
\text { Tertinggi }\end{array}$ & $\begin{array}{c}\text { Nilai } \\
\text { Terendah }\end{array}$ & X & N & S \\
\hline Kontrol & 95,00 & 55,00 & 72,16 & 30 & I I,60 \\
\hline
\end{tabular}

Berdasarkan tabel 2 tersebut hasil tes keterampilan menulis teks eksplanasi yang dilaksanakan di kelas kontrol dapat diuraikan bahwa nilai rata-rata untuk kelas kontrol 72,16 dengan jumlah siswa 30 orang. Nilai maksimal yang diperoleh siswa di kelas kontrol adalah 95,00 dengan frekuensi satu orang sedangkan nilai minimum untuk kelas kontrol adalah 55,00 dengan frekuensi satu orang. Sementara itu, simpangan baku pada kelas kontrol adalah II,60.

Berdasarkan hasil analisis data keterampilan menulis teks eksplanasi siswa kelas VII MTsN Durian Tarung Padang yang diteliti, menunjukkan bahwa siswa yang diajar dengan model pembelajaran discovery learning lebih baik dibandingkan dengan siswa yang diajar dengan model pembelajaran konvensional. Secara empiris ini terbukti dari hasil uji hipotesis yang dilakukan. Berdasarkan hasil uji hipotesis tersebut akan dilakukan pembahasan.

Pembahasan ini diuraikan pada empat pokok kajian yang dikaitkan dengan teori yang telah dikemukakan pada bagian terdahulu yaitu: (I) keterampilan menulis teks eksplanasi siswa yang diajar dengan menggunakan model pembelajaran discovery learning dan model pembelajaran konvensional, (2) interaksi antara motivasi belajar dan model pembelajaran discovery learning dalam mempengaruhi keterampilan menulis teks eksplanasi.

Hasil pengujian hipotesis pertama menunjukkan bahwa hasil secara keseluruhan keterampilan menulis teks eksplanasi siswa yang menggunakan model pembelajaran Discovery Learning lebih baik daripada kerampilan menulis teks eksplanasi siswa yang menggunakan model pembelajaran konvensional. Nilai yang diperoleh siswa pada kelas eksperimen lebih tinggi dibandingkan dengan nilai yang diperoleh siswa pada kelas kontrol.

Interaksi terjadi manakala efek faktor yang satu tergantung pada faktor yang lainnya dalam mempengaruhi sesuatu, ini sesuai dengan pendapat Irianto (20I4). Hal ini berarti bahwa masing-masing faktor antara model pembelajaran discovery learning 
Hidayati Azkiya, dkk | Pengaruh Model Pembelajaran Discovery Learning

tergantung satu sama lainnya dalam mempengaruhi keterampilan menulis teks eksplanasi siswa.

\section{Simpulan}

Simpulan ditulis secara singkat, padat dan jelas dalam satu paragraf, yang merupakan ringkasan dari hasil dan pembahasan serta menjawab dari tujuan dari penelitian/publikasi. Menekankan pada kebaharuan dari penemuan atau pengembangan. Apabila terdapat saran dari penelitian yang berkaitan dengan hasil penelitian untuk kegiatan praktis ataupun penelitian lanjutan berdasarkan hasil kebaharuan yang ditemukan dapat disampaikan secara singkat dan jelas pada akhir paragraf atau dapat membuat paragraf baru.

\section{Persantunan}

Peneliti mengucapkan terima kasih kepada pihak-pihak yang telah membantu dan terlibat dalam penelitian dan penulisan artikel ini seperti kepala sekolah dan guru bahasa Indonesia di MTsN Durian Tarung Padang

\section{Daftar Pustaka}

Arikunto, Suharsimi. (2008). Dasar-dasar evaluasi pendidikan. Jakarta: Bumi Aksara.

Azkiya, Hidayati. (2017). "Pengaruh Model Pembelajaran Aktif Tipe Card Sort dan Motivasi Belajar dalam Mata Kuliah Keterampilan Bersastra Ke SD-an Mahasiswa Prodi PGSD”. Bahastra Vol. 37 Nomor I.

Gusrayani, Diah. (2016). "Pengaruh Model Pembelajaran Discovery Learning terhadap Keterampilan Berpikir Kreatif Siswa pada Materi Sifat-Sifat Cahaya”. Jurnal Pena Ilmiah Vol.I Nomor I.

Mubarak, Chusni. (2014). Pengaruh Model Pembelajaran Discovery Learning terhadap Hasil Belajar Siswa Kelas X TAV Pada Standar Kompetensi Melakukan Instalasi Sound System di SMK Negeri 2 Surabaya" Jurnal Pendidikan Teknik elektro Volume OI nomor OI.

Priyatni, Endah Tri. (20I4). Desain pembelajaran bahasa Indonesia dalam kurikulum 2013. Jakarta: Bumi Aksara.

Siregar, Syofyan. (2010). Statistik deskriptif untuk penelitian. Jakarta: PT Raja Grafindo Persada. 